\title{
Effects of pre-treatments and drying temperatures on the quality of dried green peas
}

\section{Y.V. SHETE, M.M. MORE, S.S. DESHMUKH AND S.C. KARNE}

Received : 13.02.2015; Revised : 22.08.2015; Accepted : 19.09.2015

See end of the Paper for authors' affiliation

Correspondence to :

\section{Y.V. SHETE}

Department of Agricultural Process Engineering, Pad. Dr. D.Y. Patil College of Agricultural Engineering and Technology, Talsande, KOLHAOUR (M.S.) INDIA Email : sheteyogesh13@gmail.com
- ABSTRACT : The freshly harvested green peas procured from local market were cleaned and sorted. The average moisture content of the fresh green peas was found 70 to 75 per cent on wet basis. Three different samples of green peas with respect to pre-treatments viz., raw, blanched and blanched after pricking were taken for drying experiment. A laboratory model tray dryer was used for drying green peas with different levels of drying air temperatures $\left(50,60,70^{\circ} \mathrm{C}\right)$. Drying time, moisture reduction was calculated later with the help of observed data during tray drying. The dried green pea samples were taken for quality evaluation by sensory method, rehydration of final product was also carried out. Survey results underlined the need of technological intervention at various stages of post-harvest processing of green peas in this region. Drying of blanched green peas after pricking at $50^{\circ} \mathrm{C}$ drying air temperature resulted in shorter drying time to produce best quality dried product as compared to raw and blanched green peas. The dried green peas with final moisture content 7.52 per cent on wet basis showed best rehydration characteristics to yield good quality rehydrated peas which could be preserved and used during off-season.

- KEY WORDS : Pre-treatments, Drying time, Drying rate, Drying air temperature, Quality evaluation

- HOW TO CITE THIS PAPER : Shete, Y.V., More, M.M., Deshmukh, S.S. and Karne, S.C. (2015). Effects of pre-treatments and drying temperatures on the quality of dried green peas. Internat. J. Agric. Engg., $8(2): 220-226$. 